\title{
Anatomic considerations for C2 pedicle screw placement: the use of computerized tomography measurements
}

Considerações anatômicas sobre a localização dos parafusos pediculares em C2: utilização das medidas da tomografia computadorizada

\section{Consideraciones anatómicas de la cocalización de los tornillos pediculares en C2: vitlización de las medidas de la tomografia computadorizada}

\author{
Adebukoa Onibokun' \\ Simona Bistazzoni' \\ Marco Sassi ${ }^{1}$ \\ Larry T. Khoo'
}

\begin{abstract}
Objective: more detailed anatomical knowledge of the $\mathrm{C} 2$ pedicle is required to optimize and minimize the risk of screw placement. The aim of this study was to evaluate the linear and angular dimensions of the true C2 pedicle using axial CT. Methods: ninety three patients (47 males, 46 females mean age 48 years) who had cervical spinal CT imaging performed were evaluated for this study. Axial images of the $\mathrm{C} 2$ pedicle were selected and the following pedicle parameters were determined: pedicle width (PW, the mediolateral diameter of the pedicle isthmus, perpendicular to the pedicle axis) and pedicle transverse angle (PTA, that is, the angle between the pedicle axis and the midline of the
\end{abstract}

\section{RESUMO}

Objetivo: o conhecimento detalhado das características anatômicas do pedículo de $\mathrm{C} 2$ é necessário para minimizar os riscos relacionados com a colocação dos parafusos. O objetivo deste trabalho é avaliar as medidas lineares e angulares do eixo axial verdadeiro do pedículo de C2 utilizando tomografia computadorizada. Métodos: foram utilizadas tomografias computadorizadas axiais de 93 pacientes (47 do sexo masculino e 46 do sexo feminino) com média de idade de 48 anos. As imagens axiais do pedículo de $\mathrm{C} 2$ foram selecionadas para o estudo e os parâmetros estudados foram: largura do pedículo (diâmetro mediolateral do istmo do pedículo perpendicular ao eixo do pedículo) e o ângulo

\section{RESUMEN}

Objetivo: el conocimiento detallado de las características anatómicas del pedículo de C2 es necesario para minimizar los riesgos relacionados con la colocación de los tornillos. El objetivo del estudio fue evaluar las medidas lineares y angulares del eje axial verdadero del pedículo de C2 utilizando la tomografia computadorizada. Métodos: fueron utilizadas tomografias computadorizadas axiales de 93 pacientes (47 del sexo masculino y 46 del sexo femenino) con promedio de edad de 48 años. Las imágenes axiales del pedículo de C2 fueron seleccionadas para el estudio y los parámetros estudiados fueron: Ancho del pedículo (diámetro mediolateral del istmo del pedículo perpendicular al eje del

\footnotetext{
Study carried out of University of California - Los angeles - Comprehensive Spine Center - Santa Monica, CA, USA.

'Neurological \& Orthopedic Surgery of the University of California - Los Angeles - Comprehensive Spine Center - Santa Monica, CA.

${ }^{2}$ Assistant Professor of Neurological \& Orthopedic Surgery of the University of California - Los Angeles - Comprehensive Spine Center - Santa Monica, CA. 
vertebral body). Results: the overall mean pedicle width was $5.8+/ 1.2 \mathrm{~mm}$. The mean pedicle width in males $(6.0+/-1.3 \mathrm{~mm})$ was greater than that in the female subjects $(5.6+/-1.1 \mathrm{~mm})$. This difference was not found to be statistically significant $(p=.6790)$. The overall mean pedicle transverse angle was $43.9+/-3.9$ degrees. The mean PTA in males was $43.2+/-3.8$ degrees, while that in females was 44.7+/-3.7 degrees. Conclusion: preoperative planning is absolutely mandatory,particularlyindetermining not only screw trajectory, but in analyzing individual patient anatomy and reception to a $\mathrm{C} 2$ pedicle screw.

KEYWORDS: Cervical vertebrae/ anatomy \& histology; Tomography, X-ray computed; Bone screws tranverso do pedículo (ângulo entre o eixo do pedículo e a linha média do corpo vertebral). Resultados: o valor médio da largura do pedículo foi $5,8+/-1,2 \mathrm{~mm}$. Nos pacientes de sexo masculino o valor médio da largura do pedículo $(6,0+/-1,3 \mathrm{~mm})$ foi maior que nos pacientes de sexo feminino $(5,6+/-1,1 \mathrm{~mm})$. No entanto, não foi observada diferença estatística. O valor médio do ângulo transverso do pedículo foi de 43,9+/-3,9 graus, sendo de $43,2+/-3,8$ graus no sexo masculino e 44,7+/-3,7 graus no sexo feminino. Conclusão: o planejamento e a determinação no período pré-operatório das dimensões anatômicas do pedículo de C2 são importantes para a determinação da trajetória e dimensões do local onde o implante será colocado.

\section{DESCRITORES: Vértebras} cervicais/anatomia \& histologia; Tomografia computadorizada por raios-X; Parafusos ósseos pedículo) y el ángulo transverso del pedículo (ángulo entre el eje del pedículo y la línea media del cuerpo vertebral). Resultados: el valor promedio del ancho pedicular fue de 5.8 +/$1.2 \mathrm{~mm}$. En el sexo masculino el valor promedio del ancho del pedículo (6.0 $+/-1.3 \mathrm{~mm}$ ) fue mayor comparado con el sexo femenino $(5.6+/-1.1 \mathrm{~mm})$, sin embargo no fue observada una diferencia estadística. El valor promedio del ángulo transverso del pedículo fue de $43.9+$ +/ 3.9 grados, siendo de 43.2 +/-3.8 grados en el sexo masculino y $44.7+/$ - 3.7 grados en el sexo femenino. Conclusión: la proyección y determinación en el periodo preoperatorio de las dimensiones anatómicas del pedículo C2 son importantes para la determinación de la trayectoria y dimensiones del local donde el implante será colocado.

DESCRIPTORES: Vértebras cervicales/anatomía \& histología; Tomografía computarizada por rayos X; Tornillos óseos

\section{INTRODUÇÃO}

Posterior cervical instrumentation systems have evolved from wires to facet screws, lateral mass plates and ultimately to cervical pedicle screws. Transpedicular fixation of the cervical spine poses a particular challenge to surgeons due to the close proximity of the cervical pedicle to the spinal cord, nerve roots and the vertebral arteries. However, the biomechanical advantages afforded by cervical pedicle screws over other fixation methods are the primary driving force behind the continuing study and advancement in pedicle screw application for cervical spine fixation. Due to the small margin of error allowed for ideal cervical pedicle screw placement, even small miscalculations can result in vascular or neural injury. Therefore, accurate and intimate three dimensional knowledge of the cervical pedicles is of paramount importance.

Many cadaveric and a few radiological studies of the $\mathrm{C} 2$ pedicle have been reported ${ }^{1-6}$. However, most of these studies have actually focused on the $\mathrm{C} 2$ pars interarticularis which is distinctly different from the true pedicle. The $\mathrm{C} 2$ pars is the portion of the vertebra between the superior and inferior articular processes. Benzel 7 has commented that the $\mathrm{C} 2$ pedicle is actually the segment that joins the posterior elements with the vertebral body. We believe that more detailed anatomical knowledge of the $\mathrm{C} 2$ pedicle is required to optimize and minimize the risk of screw placement. The aim of this study was to evaluate the linear and angular dimensions of the true $\mathrm{C} 2$ pedicle using axial $\mathrm{CT}$.

\section{METHODS}

Ninety three patients who had cervical spinal multiplanar CT imaging performed for a variety of reasons were evaluated for this study. Patients were randomly chosen from the UCLA Radiology Imaging Data Bank. There were 47 males and 46 females who ranged in age from 14 to 93 years (mean 47 years). Subjects with evidence of infectious, neoplastic, traumatic or congenital spine anomalies were excluded from the study.

Cervical CT scans were performed in either of two scanners, a General Electric Light speed Helical scanner (GE Healthcare, USA) or a SOMATOM Sensation 4(Siemens Medical Solutions, Erlagen, Germany). Axial CT images were obtained using $2.5 \mathrm{~mm}$ thickness slice cuts. CT films were scanned at a resolution of $512 \times 512$ pixels, a field of view of $180 \mathrm{~mm}$ and CT Interactive software was used to edit the images. Axial images of the $\mathrm{C} 2$ pedicle were selected and the following pedicle parameters were determined using the measuring tools of the Centricity Web Imaging software; pedicle width ( $\mathrm{PW}$, the mediolateral diameter of the pedicle isthmus, perpendicular to the pedicle axis) (Figure 1) and pedicle transverse angle (PTA, that is, the angle between the pedicle axis and the midline of the vertebral body) (Figure 2). Linear parameters were measured in millimeters $+/-.1 \mathrm{~mm}$. Angular parameters were measured to the 1/10th of a degree. The measurements were performed independently by two observers. Averages and standard de 
viations were calculated for all pedicle dimensions. In addition, the frequency distribution of different pedicle widths was evaluated. All statistical analyses were performed using $R$ version 2.3.statistical analyses software ( $R$ Foundation for Statistical Computing, Vienna, Austria).

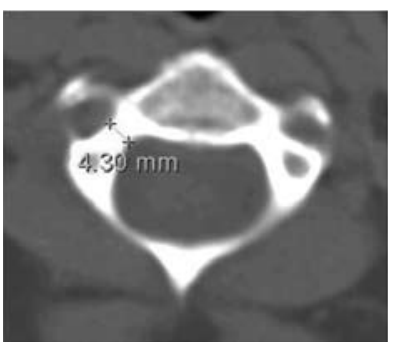

Figure 1

Pedicle width (PW)

measurements

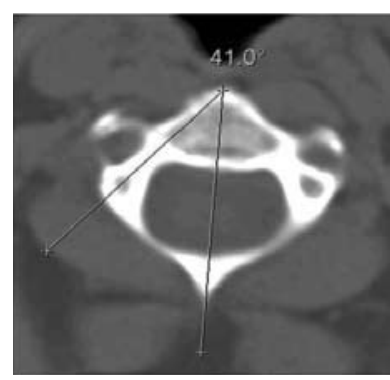

Figure 2

Pedicle transverse angle (PTA) measurements

\section{RESULTS}

The right and left $\mathrm{C} 2$ pedicle for each subject was evaluated resulting in a total of 186 pedicles measured. The means and standard deviations of the pedicle width and transverse angle were calculated for the entire patient population, as well as male and female patients separately. Intersex differences between both parameters were calculated using mixed model analysis (Mixed-effects models using S4 classes, Version .995-2). Interobserver variability analysis was performed with reasonable degree of tolerances and revealed good correlation between the measurements of the two observers.

Pedicle width - The overall mean pedicle width was 5.8+/$1.2 \mathrm{~mm}$. The mean pedicle width in males $(6.0+/-1.3 \mathrm{~mm})$ was greater than that in the female subjects $(5.6+/-1.1 \mathrm{~mm})$. This difference was not found to be statistically significant. $(p=.6790)$. The pedicle width in the male patients ranged from 2.5 to 9.6 $\mathrm{mm}$, whereas the range in the female patients was 2.6 to $9.8 \mathrm{~mm}$. With regard to the frequency distribution of pedicle widths, 5.6 $\%$ of the pedicles were $<4 \mathrm{~mm}, 24.9 \%<5 \mathrm{~mm}, 58.9 \%<6 \mathrm{~mm}$ and $84.2 \%<7 \mathrm{~mm}$ in width. $30.2 \%$ and $19.5 \%$ of female and male $\mathrm{C} 2$ pedicles respectively, were less than $5 \mathrm{~mm}$ (Table 1 and 2).

\begin{tabular}{|c|c|c|c|c|}
\hline Vertebra & $<4 \mathrm{~mm}$ & $<5 \mathrm{~mm}$ & $<6 \mathrm{~mm}$ & $<7 \mathrm{~mm}$ \\
\hline C2 & 5.6 & 24.9 & 58.9 & 84.2 \\
\hline
\end{tabular}

(expressed in percentages)

\begin{tabular}{|c|c|}
\hline Sex & $<5 \mathrm{~mm}$ \\
\hline Male & 19.5 \\
\hline Female & 30.2 \\
\hline
\end{tabular}

(expressed in percentages)
Pedicle transverse angle - The overall mean pedicle transverse angle was $43.9+/-3.9$ degrees. The mean PTA in males was 43.2 +/-3.8 degrees, while that in females was $44.7+/-3.7$ degrees. This difference was not found to be statistically significant $(\mathrm{p}=.3743$ ). The PTA ranged from 32.8 degrees to 53.2 degrees.

\section{DISCUSSION}

Multiple surgical strategies exist for the treatment of atlantoaxial instability. Posterior transarticular screw fixation confers immediate stability to the C1-C2 complex and has improved fusion rates compared to the traditional posterior wire stabilization technique ${ }^{8-}$ ${ }^{13}$.However, transarticular screw fixation is technically demanding and has several drawbacks. This technique requires reduction of $\mathrm{C} 1$ on $\mathrm{C} 2$ before screw placement. Also, the presence of a high riding vertebral artery, which may occur in up to $23 \%$ of patients, excludes this procedure as a treatment option. In addition, access to the insertion point and achievement of a correct trajectory can be restricted in some cases by unique osseous anatomy such as a pronounced thoracic kyphosis.

Relatively recently, atlantoxial fixation consisting of a screw inserted into the $\mathrm{C} 1$ lateral mass and another screw inserted into the pars or pedicle of $\mathrm{C} 2$ has been introduced ${ }_{14}$. Transpedicular fixation of the axis poses a particular challenge to surgeons due to the close proximity of the pedicle to the vertebral artery and spinal cord. Knowledge of the linear and angular parameters inherent to the $\mathrm{C} 2$ pedicle is of paramount importance in avoiding or minimizing complications associated with this technically demanding procedure. There have been several studies focusing on dimensions of the $\mathrm{C} 2$ pedicle $^{1-3,5-6}$, however the target of most of these studies has actually been the pars interarticularis. Although frequently used interchangeably in the neurosurgical and orthopedic literature, the pars and pedicle of the axis are two distinct structures. Borne et al. ${ }^{15}$ stated that the true anatomic pedicle of the axis is the narrower portion joining the complex vertebral body odontoid base to the superior articular process, while the pars interarticularis is the portion located between the superior and inferior facets. Ebraheim et al. ${ }^{1}$ defined the true $\mathrm{C} 2$ pedicle as the portion beneath the superior facet and anteromedial to the transverse foramen. The present study attempted to delineate the linear and angular parameters associated with the true pedicle of $\mathrm{C} 2$.

Karaikovic et al. ${ }^{5}$ evaluated $\mathrm{C} 2-\mathrm{C} 7$ pedicular dimensions in 53 cadaveric specimens. They obtained their measurements manually as well as by evaluating CT scans. They reported a mean C2 outer pedicle width of 6.9 and $6.5 \mathrm{~mm}$, in males and females respectively. Their results are slightly larger than those observed in this study $(6.0 \mathrm{~mm} / 5.6 \mathrm{~mm}$ for males/females). Karaikovic et al. ${ }^{5}$ reported a mean C2 PTA of 39.7 and 38.7 degrees for males and females respectively. Our mean PTA (43.2/44.7 degrees for males/females) is approximately five degrees greater than in the aforementioned study. This difference may have been caused by variations in 
the angle of the axis drawn through the pedicle by visual best fit. Our angular observations, suggest that passage into the $\mathrm{C} 2$ pedicle could only be achieved with a very medial trajectory and a lateral starting point on the posterior surface of the $\mathrm{C} 2$ pars. Our results also indicate a high degree of variability in sizes and transverse angulation of the $\mathrm{C} 2$ pedicle between individuals.

Assuming that the minimum pedicular width required is $5.0 \mathrm{~mm}$ for $3.5 \mathrm{~mm}$ screw insertion (this leaves at least $.5 \mathrm{~mm}$ of medial and lateral cortical wall thickness), based on our results, approximately $25 \%$ of pedicles at the C2 level cannot be cannulated with a $3.5 \mathrm{~mm}$ screw (Table 1). Our data showed that a higher proportion of $\mathrm{C} 2$ pedicles in our female population ( $30.2 \%$ pedicles $<5 \mathrm{~mm}$ ) cannot be fixed using $3.5 \mathrm{~mm}$ screws compared to our male population $(19.5 \%$ pedicles $<5 \mathrm{~mm}$ ) (Table 2) because of smaller pedicle diameter. Based on these findings, preoperative CT evaluation is essential, particularly in female patients, before $\mathrm{C} 2$ transpedicular fixation is considered.

\section{CONCLUSION}

Preoperative planning is absolutely mandatory, particularly in determining not only screw trajectory, but in analyzing individual patient anatomy and reception to a $\mathrm{C} 2$ pedicle screw. During this process, a trajectory representing the diameter of the proposed C2 screw needs to be safely plotted without encroachment on neurologic or vascular structures. Pedicles that are too small to cannulate are not an uncommon finding at the $\mathrm{C} 2$ level. The incorporation of image-guided technology such as frameless stereotaxis, could facilitate the navigation of narrower pedicles. These novel innovations could potentially improve accuracy of screw placement and minimize the risk of neurological and vascular injury.

\section{REFERÊNCIAS}

1. Ebraheim NA, Fow J, Xu R, Yeasting RA. The location of the pedicle and pars interarticularis in the axis. Spine. 2001;26(4):E34-7.

2. Ebraheim N, Rollins JR Jr, Xu R, Jackson WT. Anatomic consideration of the $\mathrm{C} 2$ pedicle screw placement. Spine. 1996; 21(6):691-5. Comment in: Spine. 1996; 21(19):2301-2.

3. Ebraheim NA, Xu R, Lin D, Haman S, Yeasting RA. Quantitative anatomy of the transverse foramen and pedicle of the axis. J Spinal Disord. 1998; 11(6):521-5.

4. Howington JU, Kruse JJ, Awasthi D. Surgical anatomy of the $\mathrm{C}-2$ pedicle. J Neurosurg. 2001; 95(1 Suppl):88-92.

5. Karaikovic EE, Daubs MD, Madsen RW, Gaines RW Jr. Morphologic characteristics of human cervical pedicles. Spine. 1997; 22(5):493500. Comment in: Spine. 2001; 26(23):2640-1.

6. Xu R, Nadaud MC, Ebraheim NA, Yeasting RA. Morphology of the second cervical vertebra and the posterior projection of the $\mathrm{C} 2$ pedicle axis. Spine. 1995; 20(3): 259-63.
7. Benzel EC. Anatomic consideration of $\mathrm{C} 2$ pedicle screw placement. Spine. 1996; 21(19):2301-2. Comment on: Spine. 1996; 21(6):691-5.

8. Coyne TJ, Fehlings MG, Wallace $\mathrm{MC}$, Bernstein M, Tator CH. C1-C2 posterior cervical fusion: long term evaluation of results and efficacy. Neurosurgery. 1995; 37(4): 688-92; discussion 692-3.

9. Dickman CA, Crawford NR, Paramore CG. Biomechanical characteristics of C1-2 cable fixations. J Neurosurg. 1996; 85(2): 316-22.

10.Grob D, Crisco JJ 3rd, Panjabi MM, Wang P, Dvorak J. Biomechanical evaluation of four different posterior atlantoaxial fixation techniques. Spine. 1992; 17(5): 480-90.

11. Grob D, Jeanneret B, Aebi M, Markwalder TM. Atlanto-axial fusion with transarticular screw fixation. J Bone Joint Surg Br. 1991; 73(6): 972-6.

12.Haid RW Jr, Subach BR, McLaughlin MR, Rodts GE Jr, Wahlig JB Jr. C1-C2 transarticular screw fixation for atlantoaxial instability: a 6-year experience. Neurosurgery. 2001; 49(1): 65-8; discussion 69-70.
13. Marcotte P, Dickman CA, Sonntag VK, Karahalios DG, Drabier J. Posterior atlantoaxial facet screw fixation. J Neurosurg. 1993; 79(2): 234-7.

14. Resnick DK, Benzel EC. C1-C2 pedicle screw fixation with rigid cantilever beam construct: case report and technical note. Neurosurgery. 2002; 50(2):426-8.

15.Borne GM, Bedou GL, Pinaudeau M. Treatment of pedicular fractures of the axis. A clinical study and screw fixation technique. J Neurosurg. 1984; 60(1): 88-93.

\section{Correspondência}

Larry T. Khoo,MD

Chief of Neurosurgery, UCLA SantaMonica Hospital

Assistant Professor of Neurological \& Orthopedic Surgery

University of California Los Angeles Comprehensive Spine Center

124516 th Street, Suite 200 